\section{EL MÉXICO DE CARMEN DE BURGOS}

\author{
Marta Portal \\ Departamento de Filología Española III \\ Facultad de Ciencias de la Información \\ Universidad Complutense de Madrid \\ Avda. Complutense, $s / n$ \\ 28040, Madrid
}

\begin{abstract}
The text shows in the first paragraphs Carmen de Burgos' professional personality and her style features. Marta Portal refers to su propio México (her own Mexico), that she -the authoress of the comment- knew in the few visits to that country and which is materialized in her books and in her articles about Mexico. She makes a further analysis of Carmen de Burgos' direct comments about that country as this authoress had visited and described Mexico in several articles and in a short novel entitled La Misionera de Teotihuacán (The Teotihuacán Missionary); she has also enhanced her historical and cultural knowledge along with her own participation in all matters seen and discussed. "Impressions -says Marta Portal- that can be used nowadays to illustrate the best travel guides".
\end{abstract}

KEY WORDS: Carmen de Burgos; Mexico; La misionera de Teotihuacán (The Teotihuacán Missionary); mexicanisms.

La obra de Carmen de Burgos que nos presenta la biografía de Concha Núñez es la de una auténtica forzada de las letras, que rema en los mares de todas las estructuras literarias -novelas, relatos cortos, libros de viaje, ensayos, cuentos... La honda reflexión, la clave autobiográfica-. Y estos rasgos caracterizadores de su extensa obra son concebidos desde el compromiso regeneracionista en lo ideológico, y la experimentación, en lo literario. Yo añadiría quizá, la curiosidad y el interés insobornable por entender, descifrar y comprender cuanto ve y cuanto piensa. $Y$ esa clave que nos subraya la biógrafa, como meta que persigue siempre Colombine, el bien común, en lo ideológico, tanto social como individual. Y asimismo, como espejo o como reflejo, nos lo presenta y nos lo hace conocer Concha Núñez. Fue una escritora vanguardista, tanto por los temas tratados, como por la valentía con que defendió su derecho a tratarlos.

Aquí, en esta Facultad de Periodismo, ciento cuarenta y tres años después de su nacimiento, tenemos la obligación de conocerla, de subrayar su personalidad, pues fue la primera mujer con columna fija en un periódico y la primera mujer

\section{MEXICO IN CARMEN DE BURGOS' WORKS}

RESUMEN: El texto presenta en los primeros párrafos la personalidad profesional y los rasgos de estilo de Carmen de Burgos. Marta Portal hace referencia a su propio México, que ella -la autora del comentario- conoció en varias estancias en el pais, de las que dejan constancia sus libros y artículos sobre México. Analiza los comentarios directos de Carmen de Burgos sobre el país visitado y descrito en varios artículos y la novela corta, La Misionera de Teotihuacán, su conocimiento histórico y cultural, además de su participación personal en cuanto ve y comenta. "Impresiones - dice Marta Portal- que podrian servir e ilustrar la mejor de las guias turisticas de hoy".

PALABRAS CLAVE: Carmen de Burgos; México; La misionera de Teotihuacán; mejicanismos.

corresponsal de guerra de un periódico. La naturalidad es quizá el rasgo que mejor caracteriza la personalidad de la escritora y la índole de su obra literaria.

Se me pide, o mejor dicho, se me ha destinado en el programa de este ciclo de conferencias, como cometido de participación: "México en los artículos y relatos de Carmen de Burgos". A mi propio México y a mi conocimiento del México visitado, novelado y descrito por ocho escritores británicos que he estudiado y publicado hace dos años, El Águila y el Ave Fénix', se me suma ahora esta versión y esta visita de una colega mía, que lo visitó, lo vivió y lo amó, dos o tres años antes de nacer yo, y con cuyas impresiones y entusiasmo me identifico. Y se me pide en este ciclo de conferencias que hable de ese México de los artículos y relatos de Carmen de Burgos.

El México que yo conocí, cuarenta y dos años después de Carmen de Burgos, me apasionó igualmente, como apasionó a Bernal Díaz del Castillo y como apasionó al propio conquistador, Hernán Cortés, hasta el punto de pedir en su testamento, en Castilleja de la Cuesta, Sevilla: 
Llevar mis huesos a la Nueva España, lo cual yo le encargo y mando a mi sucesor [...] que los Ileven a mi villa de Coyoacán y allí les den tierra en el monasterio de monjas que mandó hacer y edificar ${ }^{2}$.

m

3

El proyecto de viajar a México de Carmen de Burgos ya figura en una carta fechada en marzo de 1925. Ramón pensaba ir a Argentina y Carmen a México para presidir el Congreso Internacional de la Liga de Mujeres, que desde Nueva York se había convocado en enero. Se anunció en la Revista de la Raza. En esos momentos para Carmen de Burgos, la mujer escandinava era el modelo, el ejemplo a seguir. El proyecto de México con la Liga fracasó. Pero la autora viajó a México en el mes de octubre de 1925.

Las impresiones de Carmen de Burgos sobre México -publicadas en varios artículos de La Esfera- son escritas con naturalidad, con detalle, fijándose, y ofreciendo con precisión su propio entusiasmo y participación en cuanto compara y contempla. La breve referencia histórica, cultural o espacial suele provenir de su propia experiencia personal y el conocimiento cultural o turístico que tenga la autora del tema. Cuanto ve, contempla y evalúa reflexivamente, lo transmite sin reticencias ni regateos. El dato personal de la interpretación nunca es presuntuoso sino condescendiente: "Pocos lugares existen en el mundo que tengan la belleza tan completa y original como la del canal y lago de Xochimilco" (30-X-1926). Y, a continuación, la descripción:

Por el hermoso canal surcan los millares de embarcaciones que hacen un activo comercio y acarrean entre sus mercancias las flores que se cultivan en los jardines artificiales y flotantes de las chinampas.

En las descripciones de la autora está la breve referencia histórica o técnica, asentando las impresiones en el dato personal y compartiéndolas con el receptor. Podrían servir e ilustrar la mejor de las guías turísticas hoy.

En otro de sus artículos, "El teatro de Teotihuacán", publicado en un número extraordinario de La Esfera, de junio de 1929, dice:

Por eso a pesar del cuadro de color y de la gracia exótica, y algo misteriosa de las mejicanas, cuya belleza triunfa en estos momentos en el mundo con Lupe Vélez y Dolores del Río, pensamos en las terribles fiestas de la Diosa de la muerte o de Xiutecutli (Dios del fuego) que se celebraban en este lugar.

Aquí yo quiero pedir perdón al receptor por hacer un inciso novelesco y dirigirme directamente a Carmen de Burgos, Colombine:

Querida y admirada colega, yo entrevisté durante cerca de dos horas a Dolores del Río, en su hermosa casa de Coyoacán, "La Escondida", en el año 71. Seguía siendo una belleza espectacular -y conservo como prueba de esa belleza las fotos con que me obsequió la estrella en aquella entrevista.

La conversación con Dolores del Río giró fundamentalmente en torno a su profesión de actriz. Al saber que yo era novelista y estudiosa de la Literatura Hispanoamericana, me habló del proyecto que tenía de filmar El embrujo de Sevilla, de Carlos Reyles, el gran escritor uruguayo. Y a mi pregunta sobre si conocía a Buñuel, me contestó: "Admiro mucho a Buñuel pero aún no he tenido la suerte de ser dirigida por él".

Su artículo del año 29 me ha hecho meditar: Si en el 29 era ya una belleza mundialmente reconocida, ¿cuántos años tendría cuando yo la entrevisté en el 71, cuarenta y dos años más tarde?

Concha Núñez, biógrafa de Colombine, nos dice en la pág. 548 de su Biografía, al glosar las referencias léxicas, tanto históricas como costumbristas, que "tales referencias [...] configuran un espacio verosímil, conocido, inevitablemente nacido de la experiencia directa". Y habría que añadir: y lastrado con la amenaza que puede surgir de la interpretación, sobre todo si se trata de traducir o comentar campos y materias científicamente acotados, como puede ser el de vocabularios de aztequismos o el Diccionario de Mejicanismos.

Quizá el lapsus más contundente se dé en el inicio del capítulo III de su novela La Misionera de Teotihuacán:

"Cuando el automóvil se detuvo al lado de la tapia del Huacal donde habitaban los indios, acudieron una multitud de chamacos de cuatro a siete años..." (pág. 29).

Huacal, palabra de origen azteca, especie de angarillas - como un fardo hecho con cuerdas y palos que sujetan bolsas- para llevar algo de peso a las espaldas (lona o saco). Es probable que la confusión derive de la similitud 
con jacal, casa o choza de adobe con techo de paja. Casa o choza habitable.

Hay bastantes descuidos o errores -quizá de percepción oral- en las comidas mexicanas: dice endrilladas por enchiladas, polque por pulque, rebosos por rebozos, machacos por chamacos, tamanes por tamales...

$Y$ hay que reseñar igualmente grandes aciertos como cuando pondera la belleza del que llama "el más hermoso camino del mundo", que es el que sube de Veracruz a Méjico capital, Ciudad de México. Este recorrido sigue siendo hoy día ponderado por los turistas y visitantes que tienen la suerte de recorrerlo, y lo hacen con el mismo entusiasmo que nuestra autora.

Hemos de reconocer que se trata de una escritora cuyas dotes y sensibilidad hacen que nada le pase inadvertido. Matiza con perspicacia y exactitud las sólitas conductas humanas: "Con la preocupación del desembarco, volvían a ser extraños hasta los que habian formado grupos amistosos durante la travesía" (p. 9).

0 disimula el dato en una referencia de total lógica literaria. En las páginas 18 y 19 de La Misionera..., se dice: "Habian desembarcado todas las religiosas, merced a sus trajes seglares sin gran dificultad". Aquí hay una referencia histórica precisa, que se da con ambigüedad, o cierto recato. Se refiere a la repercusión política que en ese momento podían tener los hábitos religiosos, ya que el Artículo 24 de la Constitución Mexicana -desde los años de la posrevolución-, prohibía cualquier manifestación externa de culto.
El México íntimo y familiar que nos devela la novela corta, La Misionera de Teotihuacán, es el México que vive una familia como la de tantas familias españolas emigradas, en primera o segunda generación, en uno de los países hispánicos de Ultramar. Es el espacio de las relaciones personales y los valores de convivencia, pero más sensibles y agudizados en la expatriación, sea ésta forzosa o elegida por razones propias. En ella se dan el amor, el trabajo, las comidas y las fiestas comunes, los celos..., que irrumpen y acarrean la venganza mortal que hiere a la familia protagonista de la obra.

Las figuras de los personajes femeninos, de las mujeres, son más enteras, más responsables, más previsoras (se acuestan con el revólver al lado de la cama y no olvidan las pajuelas para narcotizar a los mosquitos).

En los sentimientos de los personajes se refleja la modernidad de espiritu: en cualquier lugar, en cualquier momento o circunstancia se comportan con generosidad, con amplitud de miras; se convive con respeto hacia las creencias y opiniones de los otros.

Dejamos a la Misionera de Teotihuacán, exclaustrada, en la Ciudadela, entre las grandes pirámides del Sol y la Luna, y allí, en ese espacio preciso, como si en ese suelo, en esas obras monumentales del pasado indígena -tan poco conocido y convivido por aquella Europa de 1929- se pudiera experimentar el auténtico sentir convivencial de todas las creencias, de todos los cultos que han sido ${ }^{3}$, ya que la Misionera siente vivirlo físicamente, como si todos los cultos que han sido los hiciera convivir en su alma.

\section{NOTAS}

1 Marta Portal, Agencia Española de Cooperación Internacional, 2007.

2 José Luis Martínez, Hernán Cortés, (versión abreviada), México F.C.E., 1992, p. 536.
3 Sentir que parece reflejar el ideal del eclecticismo, y ser el de la autora, Carmen de Burgos.
Recibido: 14 de mayo de 2010 Aceptado: 7 de junio de 2010 